\title{
Role of Panchakarma in the Management of Masavritavata w.r.t Dermatomyositis - A Case Study
}

\author{
Case Report
}

\section{Imtiaz Hossain Md1', Mahesh M Parappagoudra2*, Chimanda L Kamar1}

1. PG Scholar, 2. Assistant Professor, Department of Panchakarma, Parul University, Parul Institute of Ayurved, Limda, Vadodara, Gujarat, India.

\begin{abstract}
Dermatomyositis (DM) is the most frequently occurring Idiopathic Inflammatory Myopathy (IIM) of skeletal muscles causing proximal muscles weakness. The average age at which this disease affects is 40 years and almost twice as many women are affected as men. Its prevalence rate is $2-10$ per 1,00,000 in the general population. The actual cause is unknown but the disease has much common with autoimmune disorder in which your immune system mistakenly attacks our body tissue. Small blood vessel in muscular tissue are particularly affected in dermatomyositis. In this disease the ESR and CPK is usually raised. Due to similarity in the signs and symptoms, we can correlate this disease with Mamsavrita-Vata and its treatment can be planned according to it. Here is the case study of 40 years old female patient, diagnosed as Dermatomyositis since 3 months. Patient admitted in Panchakarma ward of Parul Ayurved Hospital, Vadodara. The Panchakarma procedures like Udvartana, Nitya Virechana, Basti Chikitsa, Shasti Shali Pinda Sweda and Shamana Aushadi like Cap Palsineuron and Guduchi Rasayana etc. are given. At the end of the treatment marked improvements were seen in the patient, like reduced ESR and CPK levels. Also the symptoms of the disease reduced significantly.
\end{abstract}

Key Words: Mamsavrita-Vata, Basti Chikitsa, Shastishalipinda Sweda, Nitya Virechana, Udvartana, Creatinine Phosphokinase (CPK).

\section{Introduction}

Idiopathic inflammatory myopathy (IIM) is a group of disorder characterized by inflammation of the muscle tissues along with weakness which develops gradually over a period of weeks to months or even years, other symptoms may include joint pain and general tiredness (fatigue)(1). On the basis of clinical, histopathological, immunological and Dermatographic criteria IIM are divided into 3 categories i.e. Polymyositis (PM), Dermatomyositis (DM) and Inclusion Body Myositis (IBM)(2). Dermatomyositis is the most common one among all these. Dermatomyositis (DM) is the most frequently occurring Idiopathic Inflammatory myopathy (IIM) of skeletal muscles causing proximal muscles weakness (3). The age prevalence is 30-50 years, it affects both children, adults and almost twice as many women are affected as men. The incidence is about 2-10 per million population per year (4). Patients developed skin and muscle inflammation simultaneously (5). 30\% patients develop skin manifestation prior to muscle symptoms (6). IIM associated with proximal muscles weakness, initially

* Corresponding Author:

Mahesh M P

Assistant Professor,

Department of Panchakarma,

Parul University, Parul Institute of Ayurved,

Limda, Vadodara, Gujarat, India.

Email Id: maheshmp14@gmail.com affecting large muscle of the trunk, neck and limbs. In dermatomyositis associated rash (classically described as a lilac or heliotrope discolouration) affects the upper eyelids and causes periorbital oedema and number of extramuscular clinical manifestation like fatigue, malaise, weight loss and low grade fever (7).

In Dermatomyositis, the ESR is usually raised, Antinuclear Antibodies frequently raised maybe positive in $50-80 \%$ of the patients, also elevated serum Creatinine Phosphokinase (CPK), elevated SGOT(serum glutamic oxaloacetic transaminase), SGPT( serum glutamic pyruvate transient) are seen. The line of treatment are steroidal therapy and immunosuppressive drugs (8), but these therapies comes with side effects and does not produce good result.

Based on the sign and symptoms like Kathina, Vaivarnya, Pidaka, Shvayathu, Pipilikanaga Sanchara (9), The Dermatomyositis can be correlated with Mamsavrita-Vata in Ayurveda. Ayurveda play an important role in management of Mamsavrita-Vata. The main treatment of Mamsavrita-Vata are Virechana, Niruha Basti and Shamana Aushadhi. Panchakarma treatment is basically a Bio cleansing regimen intended to eliminate the toxic elements from the body and thereby enhance immunity of the body.

\section{Case Report}

A 40 years old female, residing in Vadodara visited Panchakarma OPD (OPD.no.: 19008155) of Parul Ayurved Hospital Vadodara, with chief complaints of severe pain and stiffness in cervical region, bilateral shoulder joints, Low back region, weakness in lower 
Imtiaz Hossain Md et.al., Management of Dermatomyositis in Ayurveda through Panchakarma: A Case study

limbs, unable to sit from lying position, intermittent fever was present, puffiness of face and reddish black discolouration on the face since 3 months.

Before 3 months patient was apparently healthy, later she had gradual appearance of above-mentioned symptoms and these symptoms lead to difficulty in walking and standing for more than 5 minutes, she consulted Allopathy Doctor and was diagnosed as Dermatomyositis. She was kept on steroidal therapy for 3 months but she got only symptomatic relief. All of a sudden, these symptoms started increasing and patient had puffiness with reddish and black discolouration on the face. After this patient came to Parul Ayurved Hospital for further management. Patient was admitted in the Panchakarma IPD ward of Parul Ayurved Hospital, for better treatment.

- History of Past Illness: No clinical case of Hypertension, Diabetes or Hypothyroidism.

- On Examinations of vitals are Temperature $-98.9^{\circ} \mathrm{F}$, Pulse rate $-80 / \mathrm{min}$, Respiratory rate-20/min, Heart rate- $80 / \mathrm{min}$, Blood pressure- $130 / 80 \mathrm{mmhg}$.

- Rogi Pariksha:- Patients is having VataKapha Prakriti, predominantly VataKapha Dosha vitiation is there with involvement of Rasa Rakta Mamsa Meda Dhatu Dusti, moderate Agnibala with slight coated tounge and Avara (poor) Vyayama Shakti.

- Systemic Examination: While examining respiratory system the shape and size of chest are normal, Air entry bilaterally equal- clear no Crepitations. While examining Cardiovascular System $\mathrm{S}_{1} \mathrm{~S}_{2}$ heard, No murmur and abnormal sound heard. While examining Central Nervous System Patient was conscious, well oriented, memory was good and changes in reflexes are mention in below table (1),

\section{CNS examination (Table-1)}

\begin{tabular}{|l|l|l|}
\hline CNS Examination & Rt \& Lt & Result \\
\hline \multirow{3}{*}{ Deep Reflexes } & Bicep jerk & Normal \\
\hline & Triceps jerk & Normal \\
\hline & Knee jerk & Normal \\
\hline & Ankle jerk & Normal \\
\hline Superficial reflexes & Abdominal reflex & Normal \\
\hline Co-ordination & Plantar reflex & Normal \\
\hline Sensory examination & & Normal \\
\hline
\end{tabular}

Gastro Intestinal Tract: Abdomen is soft, no tenderness/Pain was observed.

Samprapti Ghataka:

- Dosha: -VataKapha Pradhana Tridoshaja

- Dushya: - Rasa,Rakta,Mamsa,Asthi,Majja

- Srotas:-Rasavaha, Raktavaha, Mamsavaha, Asthivaha, Majjavaha

- Srotodushti: - Sanga

- Ama: - Sama

- Udabhava sthana: -Pakwashaya

- Vyakta sthana:-Adho Shareera

\section{Figure: 1 Samprapti of MamsavrudhaVata} (Etiophatogenesis)

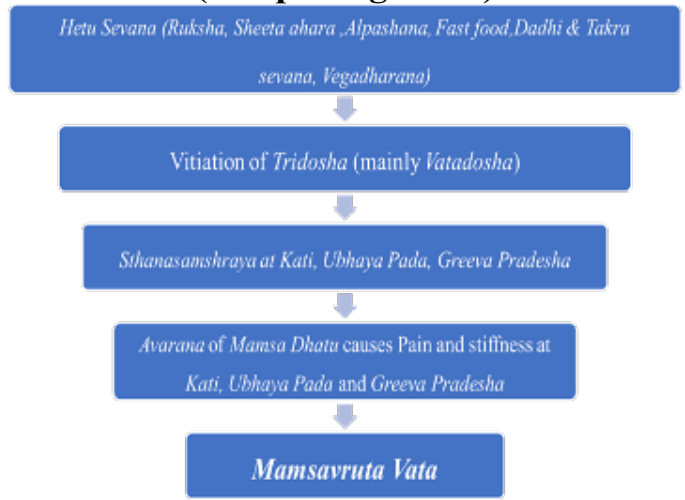

\section{Diagnosis and Treatment}

After physical examination and investigations, the patient was diagnosed with Mamsavrita-Vata (Dermatomyositis) and the patient was administered both Panchakarma procedures and Shamana Aushadhis (internal medicines). The treatments where administered in following four phases.

Note: Total 47 days of collective Panchakarma treatments was administered to the patient, for better understanding of these treatments, it is been divided into 4 phases and the reasons behind selecting each treatments is explained below. Each phase of treatment administered one after the other.

\begin{tabular}{|c|c|c|c|c|}
\hline \multicolumn{5}{|c|}{ Phase $1{ }^{\text {st }}(18 / 3 / 2019$ to $25 / 3 / 2019)$} \\
\hline I & S.N & Procedure & Days & Drugs \\
\hline & 1 & Udavartana & \multirow{4}{*}{7} & Yava churna \& Triphala churna \\
\hline & 2 & Parisheka & & Dashamoola Kashaya \\
\hline & 3 & Nitya Virechana & & Eranda taila $15 \mathrm{ml}$ with ushna jala \\
\hline & 4 & Shamana & & Panchakola phanta $100 \mathrm{ml} \mathrm{BD}(\mathrm{B} / \mathrm{F})$ \\
\hline \multicolumn{5}{|c|}{ Phase 2nd $(25 / 3 / 2019$ to $11 / 4 / 2019)$} \\
\hline \multirow[t]{2}{*}{ II } & 1 & Abhyanga & 16 & Ksheerabala taila \\
\hline & 2 & Sweda & & Shastishali Pinda \\
\hline
\end{tabular}




\begin{tabular}{|c|c|c|c|c|}
\hline & 3 & $\begin{array}{l}\text { Kala Basti } \\
\text { (Mustadiraja } \\
\text { Yapana Basti) }\end{array}$ & & $\begin{array}{l}\text { Anuvasana Basti(A) - Indukanta ghrita } 30 \mathrm{ml}+\text { Sahacharadi taila } \\
30 \mathrm{ml} \\
\text { Niruha Basti }(\mathrm{N}) \\
\text { Madhu }-80 \mathrm{gms} \\
\text { Saindhav - 8gms } \\
\text { Sneha - Indukanta ghrta + Sahacharadi taila }(80 \mathrm{ml}) \\
\text { Kalka: Madhana phala, Shatapushpa, Pippali mula, } \\
\text { Aswagandha,Musta }(20 \mathrm{gms}) \\
\text { Kwatha: Mustadi ksheerapaka }(200 \mathrm{ml}) \\
\text { Avapa-Mamsarasa-50ml }\end{array}$ \\
\hline & 4 & Shamana & & $\begin{array}{l}\text { Bala }+ \text { Erandamoola }+ \text { Arjuna Kshirapaka } 80 \mathrm{ml} \mathrm{BD}(\mathrm{B} / \mathrm{F}) \\
\text { Cap Palsineuron } 2 \mathrm{BD}\end{array}$ \\
\hline \multicolumn{5}{|r|}{ Phase $3^{\text {rd }}(11 / 4 / 2019$ to $24 / 4 / 2019)$} \\
\hline \multirow{4}{*}{111} & 1 & Abhyanga & \multirow{4}{*}{8} & Kottamchukkadi taila \\
\hline & 2 & Sweda & & Patrapindasweda \\
\hline & 3 & $\begin{array}{l}\text { Yoga basti } \\
\text { (Manjistadi } \\
\text { Kshara Basti) }\end{array}$ & & $\begin{array}{l}\text { Anuvasana Basti (A) with Manjistha oil 30ml+ Chagaladi ghrta } \\
30 \mathrm{ml} \\
\text { Niruha Basti }(\mathrm{N}) \\
\text { Madhu }-80 \mathrm{gms} \\
\text { Saindhav - } 12 \mathrm{gms} \\
\text { Sneha - Manjisthadi taila + Chagaladi ghrta }(80 \mathrm{ml}) \\
\text { Kalka: Madhana phala, Shatapushpa, Manjistha, Yashtimadhu, } \\
\text { Yavakshara }(20 \mathrm{gms}) \\
\text { Kwatha: Manjistha kashayam }(150 \mathrm{ml}) \\
\text { Avapa: Gomutra }(50 \mathrm{ml})\end{array}$ \\
\hline & 4 & Shamana & & Cap Palsineuron 2-0-2 \\
\hline \multicolumn{5}{|c|}{ Phase $4^{\text {th }}(24 / 4 / 2019$ to $08 / 05 / 2019)$} \\
\hline \multirow{4}{*}{ IV } & 1 & Abhyanga & \multirow{4}{*}{16} & Ksheerabala taila \\
\hline & 2 & Sweda & & Shastishalipinda \\
\hline & 3 & $\begin{array}{l}\text { Kala Basti } \\
\text { (Mustadi Yapana } \\
\text { Basti) }\end{array}$ & & $\begin{array}{l}\text { Anuvasana basti }(\mathrm{A}) \text { with Mahamasha taila30ml +Chagaladi ghrta } \\
30 \mathrm{ml} \\
\text { Niruha Basti }(\mathrm{N}) \\
\text { Madhu }-80 \mathrm{gms} \\
\text { Saindhav - } 8 \mathrm{gms} \\
\text { Sneha - Mahamasha taila }+ \text { Chagaladi ghrta }(80 \mathrm{ml}) \\
\text { Kalka: Madhana phala, Shatapushpa, Ashwagandha, musta, bilva } \\
\text { (20gms) } \\
\text { Kwatha: Mustadikshirapaka }(250 \mathrm{ml})\end{array}$ \\
\hline & 4 & Shamana & & Guduchi rasayana \\
\hline
\end{tabular}

Mustadiraja Yapana Basti Schedule (Table - 3)

\begin{tabular}{|l|l|l|l|l|l|l|l|l|l|l|l|l|l|l|l|l|} 
Days & 1 & 2 & 3 & 4 & 5 & 6 & 7 & 8 & 9 & 10 & 11 & 12 & 13 & 14 & 15 & 16 \\
\hline Anuvasana (A)/ Niruha(N) & A & A & N & N & N & A & N & N & N & A & N & N & N & A & N & A
\end{tabular}

Manjistadi Kshara Basti Schedule (Table - 4)

\begin{tabular}{|c|c|c|c|c|c|c|c|c|c|c|c|c|c|c|c|c|}
\hline \multirow{2}{*}{$\begin{array}{l}\text { Days } \\
\text { Anuvasana(A) / Niruha(N) }\end{array}$} & & \multicolumn{2}{|c|}{1} & \multicolumn{2}{|c|}{2} & \multicolumn{2}{|l|}{3} & 4 & \multicolumn{2}{|r|}{5} & \multicolumn{2}{|r|}{6} & \multicolumn{2}{|r|}{7} & \multicolumn{2}{|c|}{8} \\
\hline & & \multicolumn{2}{|c|}{ A } & \multicolumn{2}{|c|}{$\mathrm{N}$} & A & & $\mathrm{N}$ & & A & & $\mathrm{N}$ & & A & \multicolumn{2}{|c|}{ A } \\
\hline \multicolumn{17}{|c|}{ Mustadi Yapana Basti Schedule (Table - 5) } \\
\hline Days & 1 & 2 & 3 & 4 & 5 & 6 & 7 & 8 & 9 & 10 & 11 & 12 & 13 & 14 & 15 & 16 \\
\hline Anuvasana (A) / Niruha (N) & A & A & $\mathrm{N}$ & $\mathrm{N}$ & $\mathrm{N}$ & $\mathrm{A}$ & $\mathrm{N}$ & $\mathrm{N}$ & $\mathrm{N}$ & $\mathrm{A}$ & $\mathrm{N}$ & $\mathrm{N}$ & $\mathrm{N}$ & A & $\mathrm{N}$ & A \\
\hline
\end{tabular}

Discharge medicine for 15 days (Table - 6)

\begin{tabular}{l|l}
\hline Drugs & Dose \\
\hline 1.Kaishora Guggulu & $2-2-2$ after food \\
\hline 1.Cap Kshirabala 101 & $2-0-2$ after food \\
\hline 1.Brihatchintamani ras & $1-0-1$ after food \\
\hline 1.Manjisthadi Kashaya & $50 \mathrm{ml}-0-50 \mathrm{ml}$ before food
\end{tabular}




\section{Assessment of Results:}

\begin{tabular}{|c|c|c|c|c|}
\hline \multicolumn{5}{|c|}{ Range of Movement: Hip (Table - 7) } \\
\hline SL NO. & ROM & Before treatment & After treatment & After Follow up \\
\hline 1 & Flexion & $0-30^{0}$ & $0-70^{0}$ & $0-70^{0}$ \\
\hline 2 & Extension & $0-30^{0}$ & $0-70^{0}$ & $0-70^{0}$ \\
\hline 3 & Abduction & $0-10^{0}$ & $0-25^{0}$ & $0-25^{0}$ \\
\hline 4 & Adduction & $0-10^{0}$ & $0-25^{0}$ & $0-25^{0}$ \\
\hline
\end{tabular}

Physical examinations: (Table - 8)

\begin{tabular}{l|l|}
$\begin{array}{l}\text { Examination test } \\
\text { Coin pick test }\end{array}$ & Before treatment \\
\hline SLR test & Positive at $30^{0}$ in both leg \\
Bragard test & Positive \\
\hline Faber test & $\begin{array}{l}\text { Positive in both sides } \\
\text { (severe pain) }\end{array}$ \\
\hline Power & Lower limb +3 \\
\hline Tone & Hypertonia \\
\hline Walking time & 5mins for 20 meters \\
Gower sign & Positive \\
\hline
\end{tabular}

\section{After treatment}

Possible with slight difficulty

Positive at $70^{\circ}$ in both leg

Negative

Positive in both sides (slight pain)

Lower limb +4

Normal

2 min for 20 meters

Positive
After follow up of 30 days Possible with slight difficulty Positive at $70^{\circ}$ in both leg Negative

Positive in both sides (slight pain)

Lower limb +4

Normal

2 min for 20 meters

Positive

Specific Investigations: (Table - 9)

\begin{tabular}{|l|c|c|c|c|}
\hline \multicolumn{1}{|c|}{ Investigation } & $\mathbf{1}$ st day & After 15 days & After 30 days & After treatment \\
\hline WBC & 13810 & 8600 & 9800 & 10800 \\
\hline Hb\% & $10.4 \mathrm{gms} \%$ & $10.3 \mathrm{gms} \%$ & $10.1 \mathrm{gms} \%$ & $10.5 \mathrm{gm} \%$ \\
\hline Platelet count & 547000 & 366000 & 341000 & 417000 \\
\hline CPK & 3044 & 821 & 515.6 & 299.5 \\
\hline SGOT & 758 & 110 & 71 & 50 \\
\hline SGPT & 170 & 87 & 43 & 29 \\
\hline Protein & $+\mathrm{ve}$ & $-\mathrm{v}$ & $-\mathrm{ve}$ & $-\mathrm{ve}$ \\
\hline Uric acid & 8.2 & 7.9 & 7.7 & 7.1 \\
\hline Urea & 62 & 54 & 23 & 28 \\
\hline
\end{tabular}

Graphical presentation of results obtained:

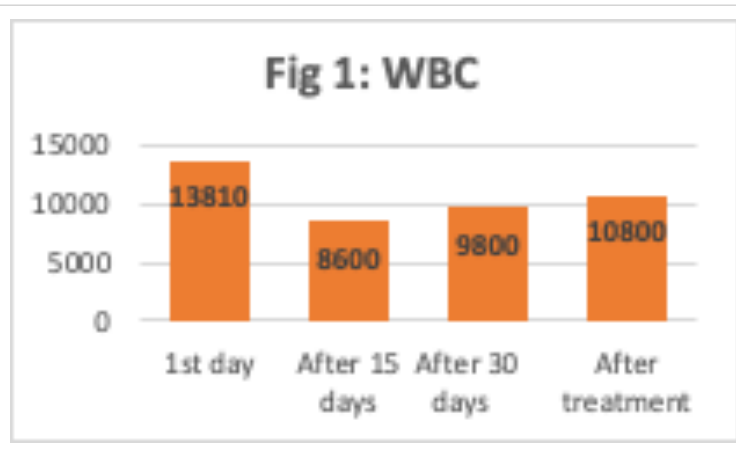

\section{Fig 2: CPK}

Flg 3: Walking time for $20 \mathrm{mts}$ (in mins)

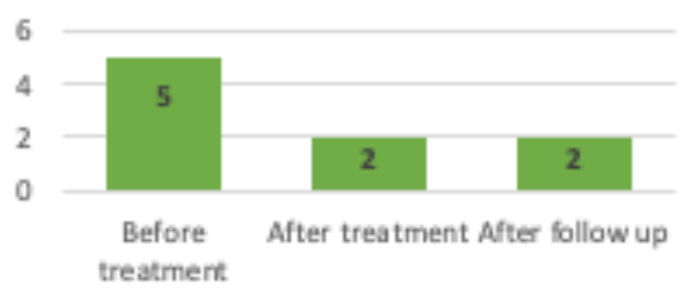

Flg 4: Uric acid

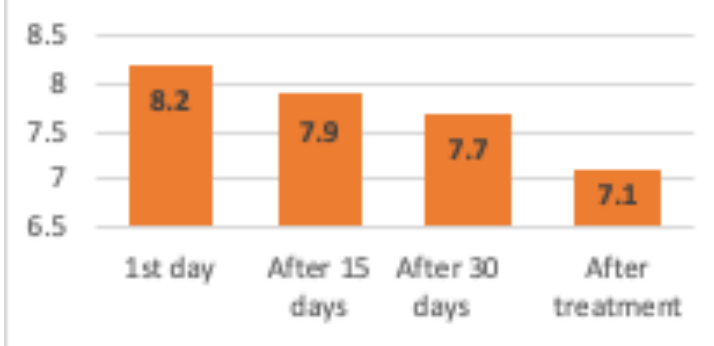




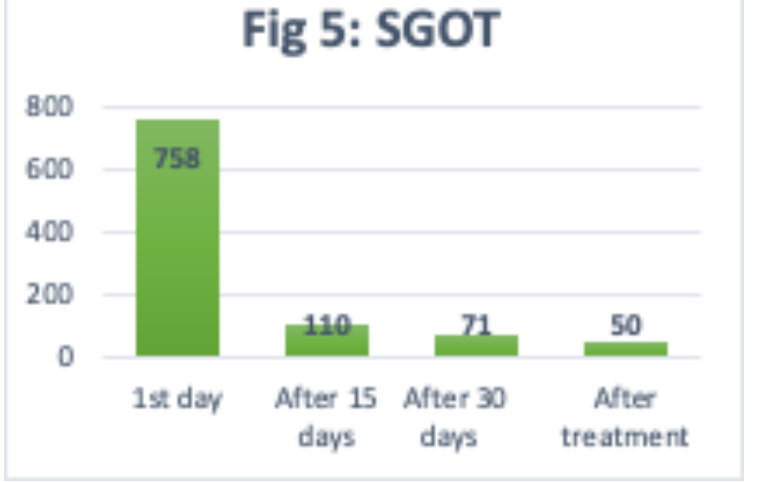

Flg 7: Power in Lower limb



Fig 6: SGPT

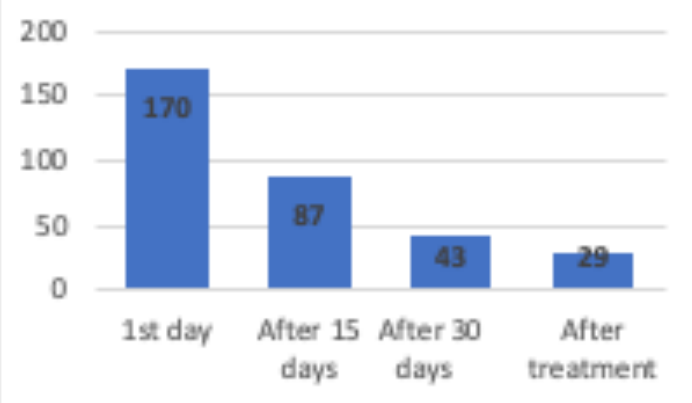

Flg 8: SLR test

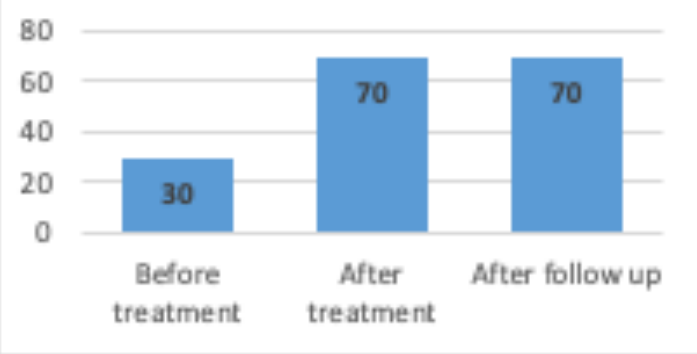

\section{Discussion}

After detail history taking and physical examinations, the patient condition was diagnose as Mamsavrita-Vata. The main line of treatment of Mamsavrita-Vata are Virechana, Niruha Basti and Shamana Aushadhi. The patient was complaining of reduced appetite, puffiness of face, stiffness and heaviness of lower limb along with pain, to treat these kind of symptoms, the treatment which are having properties like Deepana, Amapachana, Srotoshodhana and Rukshana Chikitsa are selected. So the Phase 1st treatment protocol was adopted which consists of Udvartana with Yava Churna + Triphala Churna, followed by Dashamoola Kashaya Parisheka and Nithya Virechana with Eranda Taila, along with Shamana Aushadi like Panchakola Phanta was given for 7 days.

\section{1st Phase}

- Udvartana with Yava + Triphala Churna was selected, as the Udvartana is indicated in Vataja and Kaphaja disorders, it does 'Kaphavilayana' and 'Srotoshodhana' also helps to dissolve the vitiated Meda Dhatu and promotes Agni.

- The Udvartana is generally administered in Gauravata (heaviness of body), Shula (pain all over body) and Aamaja conditions. The Yava Churna is having properties like Kashaya rasa, Ruksha Guna and Lekhana Karma (10). The Triphala Churna is having properties like Kashaya rasa, Ruksha guna and Tridosha Shamaka,Twachya, Medohara and Deepaniya (11). Hence these both drugs are selected for Udvartana during initial course (1st phase) of treatment.

- Parisheka with Dashamoola Kashaya is indicated in both PittaKaphaja and PittaVataja disorders. Also it is indicated in symptoms like Shota, Shoola, Gauravata, and Sthamba. Here the Dashamoola Parisheka Sveda might be taken as a Ruksha Drava Sveda, as it is having properties like Laghu Guna, Tridosha Shamaka, mainly Vata-Kapha Shamana (12).

- Nitya Virechana with Eranda Taila for $15 \mathrm{ml}$ with Ushna Jala in empty stomach was given, as Patient was having reduced appetite, Puffiness of face and heaviness. Virechana Karma does the Vataanulomana, Agnideepana and expels out the morbid Pitta Dosha. Eranda Taila it is having Sukshma Guna and Ushna Virya, it does elimination of the morbid Dosha from the Sukshma Srotas of the body, it also acts as Amapachana increases digestion fire i.e. Jataragni (13). Hence Eranda taila was selected for Nitya Virechana purpose.

- Panchakola Phanta was administered for Amapachana and Agnideepana, as it is having predominance in Katu Rasa, Laghu-Ruksha-Tikshna Guna and Ushna veerya (14).

- Later after achieving Samyak Deepana, Amapachana and Srotoshodhana, Phase $2^{\text {nd }}$ Bhrimhana Karma treatments were adopted i.e. Abhyanga with Ksheerabala taila, Shashtika Shaali Pinda Sweda, Mustadirajayapana Basti, and Shamana Aushadhi with Bala Churna + Erandamoola Churna + Arjuna Churna Kshirapaka and Cap Palsineuron was given for 16 days. 
$2^{\text {nd }}$ Phase

- Sarvanga Abhyanga with Ksheerabala Taila: Abhyanga does Vataanulomana, Srotoshodhana, Pustikara, and Twakdardhyakara. Ksheerabala Taila is having Vatapittashamaka, Balya, Bhrimhana and Rasayana properties. It helps to strengthen and rejuvenate nerves and muscle (15).

- Shasti Shali Pinda Sweda: It is one type of Pinda Snigdha Sweda, it contains of Shastishali, Balamoola Kwath and Ksheera. It is mainly indicated in Mamsavrita-Vata and it helps to improve muscle bulkiness and movement of both upper and lower limbs. It is mainly Brimhana in nature, it is also Vatahara and Balyakara. Ingredients like Balamoola Kashaya and Milk, are having Sheeta Virya, Balya, Brimhaniya and Vatapitta Shamana, Hence these both helps in improving muscle power, strength and also they does Dehadardhyakrita (16). Swedana does vasodilatation which increases the blood circulations and oxygen supply to the tissue as well as removal of waste material from the body which facilitates free movement of Vata Dosha leading to reduced stiffness in the body (17).

- Mustadirajayapana Basti: It is the king of all Yapana Basti mentioned in classics and can be given for longer duration without any adverse effects. It is having predominant Vatahara and Rasayana properties and does Shodhana and Brimhana Karma (18). The Acharya Charaka mentioned 'SadyoBalajanana' (improves the strength quickly) as the unique quality of Rajayapana Basti (19). Deepana and Pachana property of Mustadirajayapana Basti helps in kindling of Agni. Agni is very essential for the formation of Dhatu and process of metabolic transformation so all the dhatu get nourished well.

- Yamaka Sneha are adopted for Anuvasana Basti with Indukantam Ghrita $30 \mathrm{ml}+$ Sahacharadi taila $30 \mathrm{ml}$, because Yamaka Sneha has property of treating Dosha which situated in deeper Dhatus, Taila is mainly used for Vata Dosha Shamana and Ghrita for Pitta Dosha Shamana. The Mamsavrita-Vata is one of the Kshayaja Vyadhi by adopting Yamaka Sneha in the form of Taila and Ghrita does Brimhana Karma (nourishing the body).

- Indukantam Ghritam: It mainly contains Dashamoola, Panchakola, Yavakshara. It does as Vatakapha Shamana, Vataanulomana, Balya, Deepana-Pachana, Srotoshodhana, Shulahara and Kledahara. It can increase both Jatharagni and Dhatvagni. It mainly acts on Amashaya Sthana Udana and Samana Vata. It even acts as acts as immune modulator (20).

- Saharacharadi taila: It is having Vatakapha Shamana, Vatanulomana, Srotoshodhana, Balya, Dhatuvardhaka, Shophashulahara properties and it mainly acts on Adhakaya Vata Roga (21).

- Bala + Erandmoola + Arjuna Ksheerapaka: The milk is processed with the various Ausadhi Dravya which are found to be highly useful in curing certain ailments. Ksheera generally has the properties of being Madhura, Sheeta, Snigdha. It is AjanmaSatmya, Tustikara-Pustikara (22), increases Mamsa
Dhatu, act as Jeevaniya Shakti, reduces fatigue. It acts as Doshashamaka and Srotashodhaka. Arjuna and Bala are having Balya, Rasayana properties which promotes strength and nourishment of Dhatu or tissues. Erandamoola is having Shulaghna and Shothaghna property which helps in reducing the pain and puffiness of face (23).

- Capsule Palsinueron was given during the whole course of treatment. It is a proprietary medicine prepared by combination of Ekangaveera Ras, Mahavatavidhvamsa Ras, Sameer Pannag Ras and Sutasekhara Ras, and all these Yogas are directly indicated in Vataja Roga (24). Due to this specific type of combination, it was administered to patient to tackle symptoms like weakness and stiffness in the muscle.

- After administration of above treatments, we found better improvements in pain, stiffness, range of movements, walking time and even patient can sit from lying position without any support. We found significant changes in the laboratory investigations like $\mathrm{CPK}, \mathrm{Hb}$ gm $\%$, Serum Urea, SGPT and SGOT. However, we got no improvement in signs like puffiness of the face with reddish black discolouration. The dose of steroids where reduced.

- After completion of $2^{\text {nd }}$ Phase, certain symptoms developed like Agnimandata and Gauravata. It is due to long-term administration of Bhrimhana therapy i.e. 16 days. To reduce these symptoms, $3^{\text {rd }}$ Phase of treatment protocol adopted for 8 days i.e. Sarvanga Abhyanga with Kottamchukkadi Taila, Patrapinda Sweda, Manjisthadi Kshara Basti, Anuvasana Basti with Chagaladi Ghritam 30ml+ Manjisthadi taila $30 \mathrm{ml}$ and Shamana Aushadhi like Cap Palsineuron is given.

\section{3rd Phase}

- Sarvanga Abhyanga with Kottamchukkadi Taila: The Kottamchukkadi Taila contains more than 9 herbs, it is indicated in Vataja disorder mainly Mamsa-Medogata Vata, it has Amapachana property, it does Lekhana, Doshavilayana and Srotoshodhana which helps in relieving obstruction of Vata Dosha (25).

- Patra Pinda Sweda: Leaves of medicinal plants having analgesic and anti-inflammatory properties are the important ingredients of this procedure. It relieves stiffness, swelling and pacifies the morbidity of Vata and Kapha in the affected joints, muscles and soft tissues causes sweating and bring about lightness and a feeling of health in the affected joints, muscle and soft tissue (26).

- Manjistha Kshara Basti: Acharya Chakrapani has mentioned Kshara Basti in Niruha Basti Adhikar. The Kshara, Gomutra along with other Tikshna Dravya are used in the preparation of Kshar Basti. Kshara Basti is more effective in Kapha Avruta Vata condition. Manjisthadi Kshara Basti has antagonistic qualities towards Kapha Dosha due to Gomutra and to Pitta as well as Rakta, as it contains Manjisthadi Kwatha (27). Manjisthakshara basti acts as a Kaphapitta Shamaka, Raktaprasadana, Dipana 
Pachana, Lekhana, Varnya (28) and antiinflammatory, which helps in reduction of puffiness of face.

- Anuvasana Basti with Chagaldi Ghrita $30 \mathrm{ml}+$ Manjisthadi Taila $30 \mathrm{ml}$ was given. The Chagaladi ghrita used in the treatment of all types of Vata disorders involving emaciation, lack of strength, pain, stiffness (29). The Manjisthadi taila is mainly does Vatapitta Shamana, Twachya, Varnya, and antiinflammatory which helps in reducing discoloration of the face (30).

- After $3^{\text {rd }}$ Phase treatment protocol, the symptoms like Gaurava and Agnimandhya where reduced. At last, the $4^{\text {th }}$ Phase of treatment protocol i.e. Bhrimhana Chikitsa was adopted for 16 days i.e. Sarvanga Abhyanga with Ksheera Bala Taila, Shahti Shali Pinda Sweda, Mustadhiyapana Basti, Anuvasana Basti with Mahamasha taila with Chagaladi Ghrita and Shamana Aushadhi like Guduchi Rasayana.

\section{$4^{\text {th }}$ Phase}

- Anuvasana Basti with Mahamasha Taila (31) 30ml + Chagaladi Ghrita 30ml, both are Vata Shamana, Vatanulomana, Dhatubalya, Bhrimhaniya, Shoshahara, Sankocha Hara and Sulaprashamana. This indirectly helps to treat the symptoms like stiffness, pain and to strengthen the muscle.

- Guduchi Rasayana: It was administered in empty stomach once daily with restricted diet regimen. i.e.

Guduchi Rasayana: (Table no:- 10)

\begin{tabular}{|l|l|}
\hline No. of Tablets & No. of Days \\
\hline 4 tabs & $1-4$ days \\
\hline 8 tabs & $5-8$ days \\
\hline 16 tabs & $9-12$ days \\
\hline 8 tabs & $13-16$ days \\
\hline 4 tabs & $17-20$ days \\
\hline
\end{tabular}

The term Rasayana refer to nourishment or nutrition. Rasayana drugs acts essentially on nutrition dynamics and rejuvenate the body and psyche. Rasayana drugs also promotes intellect and strength, prolongation of life. By the use of Rasayana Karma one can attain longevity, excellence of lustre, complexion, optimum strength of physique. The meaning of word Rasayana is to attain the excellence quality of Rasa Dhatu. It is having Ushna Virya and Tridosha Shamaka property. It acts as an Immune modulator and antioxidant (32). Based on the signs and symptoms of dermatomyositis i.e. inflammation of the skin, degeneration of the muscle tissues, discolouration, swelling, and as an auto immune condition, the Guduchi Rasayana was selected for treatment, as it has a good effect on these symptoms. It was given in Vardhaman matra i.e. increasing dosage form, starting with 4 tablets for 4 days upto 16 tablets then gradually decrease to 4 tablets (Table no: 9).

\section{Conclusion}

The present case study justifies the successful management of Dermatomyositis (Mamsavrita-Vata) through Panchakarma procedures along with certain
Shamanaushadi (Internal medicines). In this case study the patient was administered Panchakarma treatments in acute stage, hence got better improvements in her symptoms and laboratory investigations like CPK, SGOT, SGPT, Uric acid and WBC count (due to presence of traces pathology in patient there was raise in WBC count during discharge). The disease diagnosing factor i.e. CPK level came to normal, i.e. before treatment it was $3400 \mathrm{IU}$ and after treatment it was $299 \mathrm{IU}$. We found very less improvement in signs like Puffiness of face and discolouration of face. This single case proved the importance of Panchakarma treatments in the management of Dermatomyositis (Mamsavrita-Vata). But there is need of large number of sample size to standardize the Panchakarma treatment protocol, in the management of Dermatomyositis.

\section{References:}

1. Munjal. Y.P, (2015) Tenth edition, API textbook of Medicine Vol I, Jaypee Brothers Medical Publishers (P) Ltd. New Delhi.

2. Munjal Y.P. (2015) Tenth edition, API textbook of Medicine Vol I, Jaypee Brothers Medical Publishers (P) Ltd. New Delhi.

3. Das P.C. \& Das P.K.. (2013) fifth edition, Text Book of Medicine Pg 455, Currentt Books International 60, lenin saranee kolkatta.

4. Das P.C. \&. Das P.K. (2013) fifth edition, Text Book of Medicine Pg 456, Currentt Books International 60, lenin saranee kolkatta.

5. George $\mathrm{K}$ M. \& $\mathrm{P}$ Aggarwal., fifth edition, Medicine prep manual for undergraduates P 745, ELSEVIER

6. George K M. \& P Aggarwal. fifth edition, Medicine prep manual for undergraduates P 745, ELSEVIER

7. Munjal Y.P, (2015) Tenth edition, API textbook of Medicine Vol I, Jaypee Brothers Medical Publishers (P) Ltd. New Delhi.

8. George. K M \& Aggarwal P., fifth edition, Medicine prep manual for undergraduates P 745, ELSEVIER

9. Sharma R, \& Dash. B, (2013). Caraka Samhita, Vol V(p. Pg 38). Varanasi: Chowkhambha Sanskrit.

10. Jain R.., Jain P., \& Patil S. (2013). Yava(Barley)Akey to the life style disorder. Ayurpharm Int $J$ Ayur, (138-143).

11. Shafeer V.M. (2014). Samhita of Ayurvedic medical specialities (3rd ed., p. Pg 580). Tamil Nadu: Dr Y.Mahadeva Iyer's Srisarada Ayurveda Hospital.

12. Shafeer V.M. (2014). Samhita of Ayurvedic medical specialities (3rd ed., p. Pg 210). Tamil Nadu: Dr Y.Mahadeva Iyer's Srisarada Ayurveda Hospital.

13. Kamat S. (2016). Bhavaprakasha nighantu (1st ed., p.236). Varanasi. Chaukhambha Sanskrit.

14. Shafeer V.M. (2014). Samhita of Ayurvedic medical specialities (3rd ed., p. Pg 138). Tamil Nadu: Dr Y.Mahadeva Iyer's Srisarada Ayurveda Hospital.

15. Shafeer V.M. (2014). Samhita of Ayurvedic medical specialities (3rd ed., p. Pg 439). Tamil Nadu: Dr Y.Mahadeva Iyer's Srisarada Ayurveda Hospital.

16. Patel M. (2019). Pakshaghata and its management through Panchakarma- A case study. Wjpps, $8(2$, 1473-1480). 
17. H, M. (1998). Fundamental of Anatomy and physiology (4th ed., p. Chp 5). New Jersy: Inc.Simon and Schuster.

18. Govindas, Bhaishajya Ratnavalli, Balaroga Chikitsa Prakaran,71/48, edited by B.H.Mishra, A.S. Shastri, reprinted Chaukhambha Prakadhan, Varanasi, 2013;1217-8.

19. Govindas, Bhaishajya Ratnavalli, Balaroga Chikitsa Prakaran,71/48, edited by B.H.Mishra, A.S.Shastri, reprinted Chaukhambha Prakadhan, Varanasi, 2009,678.

20. Shafeer V.M. (2014). Samhita of Ayurvedic medical specialities (3rd ed., p. Pg 478). Tamil Nadu: Dr Y.Mahadeva Iyer's Srisarada Ayurveda Hospital.

21. Shafeer V.M. (2014). Samhita of Ayurvedic medical specialities (3rd ed., p. Pg 470). Tamil Nadu: Dr Y.Mahadeva Iyer's Srisarada Ayurveda Hospital.

22. Gholap AH, Mahajan MP., Gupta MK.,An Ayurvedic review of medicated milk from Charak Samhita w.s.r to its Internal usage in various diseases. IJAPR,2015;3(5):1-5.

23. Lucas D.S,. Dravyaguna-Vijnana Study of DravyaMaterial Medica Vol II Chaukhambha Bharati Academy Varanasi,2012 pg47,167, 389.

24. Palsinuron Capsule-Uses,Side-effect,Reviews, and precautions- S G Phyto pharma- Tablet wise.
25. Clinical study report on Migraine [Internet]. [cited 2

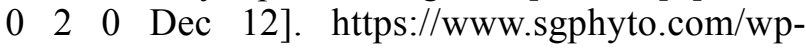
content/uploads/2017/06/Palsinuron-Capsule.pdf

26. Kumar T. \& A.Thakar, Kottamchukkadi taila: A theoretical analysis, WJPR Vol 7,issue 9,2018

27. Bhusal, N. S. Prakash \&G. Mangal., A review on Patra Pinda Sweda: A peculiar Ayurveda bolus fomentation, IAMJ, may 2017.

28. Acharya YT; et al; Sushrut Samhita with Nibandha Sangraha and Nayachandrika commentary. Varanasi, Chaukhambha Sanskrit Sansthan, Edition2012, Sutrasthana, Chapter11, pgno-45

29. Shafeer V.M. (2014). Samhita of Ayurvedic medical specialities (3rd ed., p. Pg 432). Tamil Nadu: Dr Y.Mahadeva Iyer's Srisarada Ayurveda Hospital.

30. Rao GP, Bhaisajya Ratnavali of Kaviraj Shri Govind das Sen Vatavyadhi adhikara pg 436-461, Chaukhambha Orientalia Varanasi,2014

31. Shafeer V.M. (2014). Samhita of Ayurvedic medical specialities (3rd ed., p. Pg 584). Tamil Nadu: Dr Y.Mahadeva Iyer's Srisarada Ayurveda Hospital.

32. Shafeer V.M (2014). Samhita of Ayurvedic medical specialities (3rd ed., p. Pg 466). Tamil Nadu: Dr Y.Mahadeva Iyer's Srisarada Ayurveda Hospital.

33. Acharya VY, Editor. Sushruta Samhita of Sushruta, Sutrasthana, Ch.1, Ver.8,7th edition, Varanasi, Choukhamba Orientalia 2002. 